\title{
Pengelolaan Pemangkasan Tanaman Kopi Arabika (Coffea arabica L.) di Kebun Kalisat Jampit, PT Perkebunan Nusantara XII (Persero), Bondowoso, Jawa Timur
}

\author{
Pruning Management of Arabica Coffee (Coffea arabica L.) at Kalisat Jampit Estate, PT \\ Perkebunan Nusantara XII (Persero), Bondowoso, East Java
}

\author{
Nur Khayati, Ade Wachjar*, Sudarsono \\ Departemen Agronomi dan Hortikultura, Fakultas Pertanian, Institut Pertanian Bogor \\ (IPB University), Jl. Meranti, Kampus IPB Darmaga, Bogor 16680, Indonesia \\ Telp. \& Faks.62-251-8629353 e-mail agrohort@apps.ipb.ac.id \\ *Penulis Korespondensi : wachjar@apps.ipb.ac.id
}

Disetujui : 28 April 2020 / Published Online Mei 2020

\begin{abstract}
The goal of research was to analyze and identify the problems in the pruning system of coffee. In addition, cultivating work skills and increasing knowledge regarding coffee cultivation. The research was conducted at Kalisat Jampit Estate, PT Perkebunan Nusantara XII (Persero), Bondowoso, East Java from January to May 2019. Coffee is one of the most important commodity plantations in the Indonesian economy. One important coffee cultivation technique is pruning. Observations were made on trimming aspects which included plant height, branch composition, and shoot growth. Plant samples are taken from five garden blocks and they're made up of three plants per block. Secondary data is obtained from company management reports. Data analysis was carried out descriptively, averaged, and percentage. Pruning of the coffee plants in the Kalisat Jampit Estate is done including trimming maintenance/production. The composition of productive branches that are evenly distributed ( $\pm 33 \%)$ will affect the results of the estimated production. The part of pruned branches is a branch that is old, has disease, and its production has decreased. Pruned branches will grow new productive shoots. The performance of pruning in the Afdeling Kampung Baru according to plantations standards is seen from a coffee plant not more than 160 centimeters high.
\end{abstract}

Keywords : coffee, pruning, shoot, productive branches

\begin{abstract}
ABSTRAK
Kegiatan penelitian ini bertujuan menganalisis dan mengidentifikasi permasalahan yang dihadapi dalam kegiatan pemangkasan kopi. Selain itu, melatih keterampilan kerja dan menambah pengetahuan terkait budidaya kopi. Kegiatan penelitian telah dilaksanakan di Kebun Kalisat Jampit, PT Perkebunan Nusantara XII (Persero), Bondowoso, Jawa Timur pada bulan Januari sampai bulan Mei 2019. Kopi merupakan salah satu komoditas perkebunan yang memegang peranan penting dalam perekonomian Indonesia. Salah satu teknik budidaya tanaman kopi yang penting adalah pemangkasan. Pengamatan dilakukan pada aspek pemangkasan yang meliputi tinggi tanaman, komposisi cabang, dan pertumbuhan tunas. Sampel tanaman diambil dari 5 blok kebun dan terdiri atas 3 tanaman per blok. Data sekunder diperoleh dari laporan manajemen perusahaan. Analisis data yang dilakukan secara deskriptif, rata-rata, dan persentase. Pemangkasan tanaman kopi yang dilakukan di Kebun Kalisat Jampit termasuk pemangkasan pemeliharaan/produksi. Komposisi cabang produktif yang merata $( \pm 33 \%)$ akan berpengaruh terhadap hasil taksasi produksi. Jumlah cabang yang dipangkas merupakan cabang yang sudah tua, terserang penyakit, dan produksinya sudah menurun. Cabang yang sudah dipangkas akan menumbuhkan tunas-tunas produktif yang baru. Pelaksanaan pemangkasan di Afdeling Kampung Baru sudah sesuai dengan standar kebun dilihat dari tinggi tanaman kopi yang tidak lebih dari $160 \mathrm{~cm}$.
\end{abstract}

Kata kunci : kopi, pemangkasan, tunas, cabang produktif 


\section{PENDAHULUAN}

Kopi merupakan komoditas perkebunan yang memegang peranan penting bagi perekonomian Indonesia. Luas perkebunan kopi di Indonesia terbagi menjadi Perkebunan Rakyat (PR) sebesar 96\%, Perkebunan Besar Negara (PBN) dan Perkebunan Besar Swasta (PBS) yang masing-masing sebesar 2\% (Ditjenbun, 2015). Areal perkebunan kopi tahun 2013 seluas $1,214,712$ ha dengan produksi 675,881 ton, nilai ekspor yang dihasilkan US\$ $1,174.029$ juta dari volume ekspor 534,023 ton. Luas areal kopi tahun 2017 meningkat menjadi 1,251,703 ha dengan produksi menurun menjadi 666,992 ton, nilai ekspor yang dihasilkan meningkat menjadi US\$ 1,187.157 juta dari volume ekspor sebesar 467,800 ton. Produktivitas kopi tahun 2013 sebesar $544 \mathrm{~kg} \mathrm{ha}^{-1}$, meningkat pada tahun 2017 menjadi $720 \mathrm{~kg} \mathrm{ha}^{-1}$ (BPS, 2018). Nilai tersebut jika dibandingkan dengan tahun 2013, pada tahun 2017 terjadi peningkatan luas lahan, nilai ekspor, dan produktivitas kopi, sedangkan produksi dan volume ekspor mengalami penurunan.

Jenis tanaman kopi yang banyak dibudidayakan di Indonesia yaitu kopi Arabika (Coffea arabica) dan kopi Robusta (Coffea canephora). Luas areal tanaman kopi Arabika sekitar 26\% dan kopi Robusta sekitar 74\%. Kopi Arabika merupakan jenis kopi yang ditanam paling awal daripada kopi Liberika dan kopi Robusta. Kopi Arabika tumbuh baik pada ketinggian 1,000-2,100 meter di atas permukaan laut (dpl) (Panggabean, 2011).

Salah satu kegiatan pemeliharaan tanaman kopi yang perlu dilakukan yaitu pemangkasan. Pemangkasan merupakan salah satu kegiatan kultur teknis yang secara teratur selalu dilakukan agar tanaman kopi tumbuh sehat dan produktif (Rahardjo, 2012). Pemangkasan bertujuan untuk membentuk tajuk, membuang bagian tanaman yang terserang hama penyakit, membuang tunas air dan batang yang negatif, serta meningkatkan sirkulasi udara (Martini et al., 2017). Sistem pemangkasan tanaman kopi dibagi menjadi dua yaitu pemangkasan batang tunggal dan pemangkasan batang ganda (Rahardjo, 2012). Pemangkasan batang tunggal memiliki tiga tahap pemangkasan, yaitu pemangkasan bentuk, produksi, dan peremajaan. Pemangkasan bentuk dilakukan pada saat tanaman muda umur 1-2 tahun yang belum menghasilkan. Tujuan pemangkasan bentuk agar tumbuh cabang primer baru dari cabang yang disunat sehingga terbentuk tajuk pohon. Kegiatan pemangkasan bentuk dilakukan dengan memangkas batang (toping) sekaligus atau secara bertahap dan dilakukan juga beberapa penyunatan cabang primer (Rahardjo, 2017).

Pemangkasan produksi adalah pemangkasan yang dilakukan pada tanaman yang telah menghasilkan atau berbuah. Pemangkasan produksi terdiri atas pemangkasan ringan dan berat. Pemangkasan ringan terdiri atas wiwil kasar dan wiwil halus. Wiwil kasar dilakukan satu bulan sekali pada musim hujan dan dua bulan sekali pada musim kemarau, sedangkan untuk wiwil halus dilakukan tiga bulan setelah panen dan diulang tiga bulan kemudian (Sudarko, 2012). Pemangkasan berat dilakukan segera setelah panen kopi selesai sehingga disebut juga pangkasan lewat panen atau panglepan. Cabang yang dipangkas adalah cabang-cabang tua yang telah berbuah dua kali, cabang sakit, cabang kering. Apabila belum terbentuk cabang sekunder, pemangkasan perlu dilakukan dengan menyisakan 2-3 ruas dari pangkal cabang primer (Rahardjo, 2017). Pemangkasan pemeliharaan dilakukan minimal 1 tahun sekali pada pohon yang sudah mulai berproduksi dengan tujuan merangsang pembentukan bunga dan proses penyerbukan, menyediakan cabang-cabang buah pada tahun berikutnya, dan mempermudah proses pemanenan (Martini et al., 2017).

Pemangkasan rejuvinasi (peremajaan) dilakukan pada tanaman tua yang kurang produktif tetapi perakarannya masih kokoh. Pelaksanaan rejuvinasi yang tepat adalah pada saat menjelang musim hujan setelah panen kopi selesai (Atrisiandy, 2015). Peremajaan dapat dilakukan dengan 2 cara yaitu peremajaan dengan penyambungan secara selektif dan peremajaan secara menyeluruh, dengan perencanaan sebelumnya (Subandi, 2011). Menurut Mulyono et al. (2016) rendemen terendah terdapat pada pola pemangkasan kopi tanpa dipangkas yaitu $14.14 \%$ dan yang tertinggi terdapat pada pola pangkasan kopi yang dipangkas ringan yaitu $15.04 \%$.

Pelaksanaan kegiatan penelitian bertujuan untuk meningkatkan pengetahuan dan pengalaman mengenai teknik budidaya tanaman kopi Arabika (Coffea arabica L.), menambah dan melatih keterampilan kerja di lapangan. Selain itu, kegiatan penelitian juga bertujuan mempelajari aspek pemangkasan lebih mendalam serta menganalisis masalah-masalah pemangkasan yang dihadapi di lapangan berikut solusinya. 


\section{METODE}

Kegiatan penelitian dilaksanakan di Kebun Kalisat Jampit, PT Perkebunan Nusantara XII (Persero), Bondowoso, Jawa Timur. Kegiatan penelitian dilaksanakan selama empat bulan, mulai Januari sampai Mei 2019. Selama pelaksanaan penelitian penulis bekerja secara langsung di kebun sebagai karyawan harian lepas (KHL) selama satu bulan, pendamping mandor selama satu bulan, dan sebagai pendamping asisten selama dua bulan. Data yang diambil selama penelitian terdiri atas data primer dan data sekunder. Data sekunder diperoleh dari laporan bulanan, triwulanan, semesteran, dan tahunan yang terkait dengan keadaan umum perusahaan meliputi letak geografis dan wilayah administratif, keadaan tanah dan iklim (curah hujan), luas areal konsesi atau hak guna usaha dan tata guna lahan, keadaan tanaman dan produksi, serta struktur organisasi dan ketenagakerjaan.

Data primer adalah data yang diperoleh dari hasil pengamatan langsung terhadap tanaman dan kualitas tenaga pemangkas, serta kegiatan diskusi dengan mandor, asisten atau tenaga pemangkas yang berkaitan dengan aspek pemangkasan. Data primer diperoleh dari pengamatan langsung di lima blok tanaman menghasilkan (TM). Setiap blok diambil tiga tanaman contoh secara acak sistematis. Pengamatan dibagi menjadi dua tahap yaitu pengamatan sebelum pemangkasan dan pengamatan setelah pemangkasan, pengamatan sebelum pemangkasan meliputi jadwal pemangkasan, jenis pemangkasan, kondisi tanaman meliputi tinggi tanaman, jumlah cabang total, dan komposisi cabang yang meliputi jumlah cabang belum berbuah (B0), jumlah cabang berbuah satu kali (B1), jumlah cabang berbuah dua kali (B2), dan jumlah cabang berbuah tiga kali (B3). Pengamatan setelah pemangkasan meliputi tinggi tanaman setelah dipangkas, jumlah cabang total, dan jumlah tunas yang tumbuh. Pengamatan tinggi tanaman diambil dengan cara mengukur tanaman dari permukaan tanah sampai titik teratas kuncup tunas air. Cabang tidak produktif dihitung dari jumlah cabang sakit, kering, dan rusak/patah. Berdasarkan hasil kegiatan tersebut diperoleh data prestasi kerja penulis dan hambatan atau pendukung dari kegiatan yang dilakukan.

Hasil pengamatan terdiri atas data primer dan data sekunder. Data tersebut dianalisis dengan menggunakan metode analisis deskriptif, persentase, dan nilai rata-rata. Hasil olahan data dibandingkan dengan standar yang ditetapkan kebun dan pustaka.

\section{KEADAAN UMUM}

Kebun Kalisat Jampit terletak di Desa Kalisat, Kecamatan Ijen, Kabupaten Bondowoso, Jawa Timur. Kebun Kalisat Jampit memiliki letak geografis $96.80{ }^{\circ} \mathrm{LS}$ dan 06.60 ${ }^{\circ} \mathrm{BT}$. Letak ketinggian kebun ini antara 1,100-1,500 meter dpl. Kebun Kalisat Jampit memiliki tipe iklim CD (menurut Schmidth-Ferguson). Curah hujan rata-rata selama lima tahun terakhir (2014-2018) yaitu 1,571 mm tahun ${ }^{-1}$ dengan hari hujan 125 hari serta bulan basah 6 bulan dan bulan kering 5 bulan. Kelembaban udara rata-rata $82 \%$ dengan kelembaban tertinggi $95.70 \%$ dan kelembaban terendah 57.40\%. Rata-rata suhu di Kebun Kalisat Jampit yaitu $18{ }^{\circ} \mathrm{C}$ dengan suhu tertinggi $40{ }^{\circ} \mathrm{C}$ dan suhu terendah $5{ }^{\circ} \mathrm{C}$. Jenis tanah di kebun ini yaitu Andosol dengan struktur remah, porositas baik, dan pH tanah 5.5-6.6.

Kebun Kalisat Jampit merupakan salah satu kebun milik PT Perkebunan Nusantara XII (PTPN XII) yang bergerak dibidang agrobisnis dan agroindustri. Kebun ini memiliki luas hak guna usaha (HGU) 3,105.42 ha. Luas areal tanaman menghasilkan Kebun Kalisat Jampit $1,355.24$ ha dengan jumlah tanaman produktif 3,250,658 tanaman. Rata-rata produksi selama lima tahun terakhir (2014-2018) sebesar 741,071 kg biji kopi kering dengan produktivitas rata-rata sebesar $553 \mathrm{~kg} \mathrm{ha}^{-1}$. Struktur organisasi tertinggi Kebun Kalisat Jampit adalah manajer. Total tenaga kerja di Kebun Kalisat Jampit adalah 967 orang yang terdiri atas karyawan tetap dan karyawan lepas.

\section{HASIL DAN PEMBAHASAN}

\section{Pemangkasan}

Pemangkasan merupakan salah satu kegiatan kultur teknis yang secara teratur harus dilakukan agar tanaman kopi tumbuh sehat dan produktif (Rahardjo, 2012). Tujuan pemangkasan agar memiliki tinggi yang mudah dijangkau sehingga mempermudah pemeliharaan tanaman, menyediakan cabang-cabang baru yang lebih produktif, dan dapat mengurangi biennial bearing sehingga produksi dapat stabil. Pemangkasan dibagi menjadi dua, yaitu pemangkasan batang tunggal dan pemangkasan batang ganda. Pemangkasan batang tunggal terdiri atas pemangkasan bentuk, pemangkasan pemeliharaan atau produksi, dan pemangkasan peremajaan atau rejuvinasi. Pemangkasan pemeliharaan dibagi menjadi tiga, yaitu pemangkasan lepas panen (PLP), wiwil halus atau selektif, dan wiwil kasar. 
Pemangkasan lepas panen (PLP) di Afdeling Kampung Baru pada tahun 2018 dilaksanakan pada bulan September-Oktober. PLP dilaksanakan segera setelah panen kopi selesai. Keberhasilan PLP dapat dilihat dari kondisi percabangan tahun berikutnya. Selain itu, pemangkasan pemeliharaan lain juga dilakukan di Kebun Kalisat Jampit. Wiwil kasar dan wiwil halus dilaksanakan pada bulan Februari. Hal ini sesuai dengan standar yang ditetapkan kebun yaitu melakukan wiwil 3 bulan setelah PLP dan diulang 2-3 bulan kemudian jika diperlukan. Pemangkasan pemeliharaan dilakukan untuk memangkas tunas air, cabang adventif seperti cabang sakit, cabang kering, cabang balik.

Kriteria pemangkasan dibagi menjadi tiga, yaitu pangkas berat, sedang, dan ringan. Pemangkasan yang dilakukan tergolong pangkas ringan sesuai dengan standar PT Perkebunana Nusantara XII yaitu dengan mewiwil kasar tunas air dan mewiwil selektif di mana kondisi cabang B0, B1, B2 dalam proporsi seimbang yaitu $\pm 33 \%$ serta cabang B2 tetap dipertahankan. Kegiatan pemangkasan ini juga dilakukan agar unsur hara yang diserap dapat bermanfaat bagi cabangcabang yang produktif.

\section{Jenis-Jenis Cabang}

Arah pertumbuhan tanaman kopi terdiri atas dua, yaitu pertumbuhan ke atas (orthotrop) dan pertumbuhan ke samping (plagiotrop). Sebelum melakukan pemangkasan, cabangcabang pada tanaman diidentifikasi. Masingmasing cabang tersebut memiliki jumlah buah yang berbeda. Pengamatan rata-rata komposisi cabang disajikan dalam Tabel 1.

Berdasarkan Tabel 1, komposisi cabang pada tanaman sampel bervariatif. Komposisi cabang B0 (belum berbuah) paling banyak terdapat pada Blok Kina, cabang-cabang B1 paling banyak terdapat pada Blok Selok, cabang B2 paling banyak pada Blok J, dan cabang B3 yang telah berbuah tiga kali paling banyak terdapat pada Blok Bawang. Hal ini berarti pada tahun yang akan datang Blok Kina akan memiliki jumlah cabang produktif lebih banyak, sedangkan Blok Bawang perlu dilakukan pemangkasan pemeliharaan untuk menumbuhkan cabang reproduktif. Pengamatan persentase jumlah cabang berdasarkan komposisi cabang dan produksi tanaman kopi disajikan dalam Tabel 2.

Hasil pengamatan pada Tabel 2, menunjukkan bahwa Blok Sabrang memiliki persentase komposisi cabang yang paling seimbang diantara blok lainnya. Blok Selok juga memiliki proporsi yang tidak berbeda antara B0, B1, B2, dan B3. Akan tetapi, berdasarkan Tabel 1, Blok Selok memiliki jumlah rata-rata proporsi cabang yang lebih sedikit daripada Blok Sabrang. Hal ini akan mempengaruhi jumlah taksasi buah pada masing-masing blok.

Hasil taksasi produksi paling banyak terdapat pada Blok Sabrang, sedangkan hasil taksasi paling sedikit yaitu Blok Selok yang hanya $0.29 \mathrm{~kg}$. Hal ini mungkin saja terjadi karena kondisi pertanaman yang berbeda serta waktu berbuah yang terlambat.

Proporsi cabang berdasarkan pengamatan paling baik yaitu pada blok Sabrang. Persentase antara B0, B1, B2, B3 tidak terlalu jauh berbeda yaitu $46,26,13$, dan 14\%. Kondisi tanaman yang seperti ini juga akan berpengaruh terhadap produksi. Tabel 2 menunjukkan pada Blok Sabrang memiliki proporsi komponen cabang yang baik sehingga memberikan hasil taksasi buah paling besar jika dibandingkan dengan blok lainnya.

Tabel 1. Rata-rata komposisi cabang tanaman kopi Arabika di Afdeling Kampung Baru Kebun Kalisat Jampit

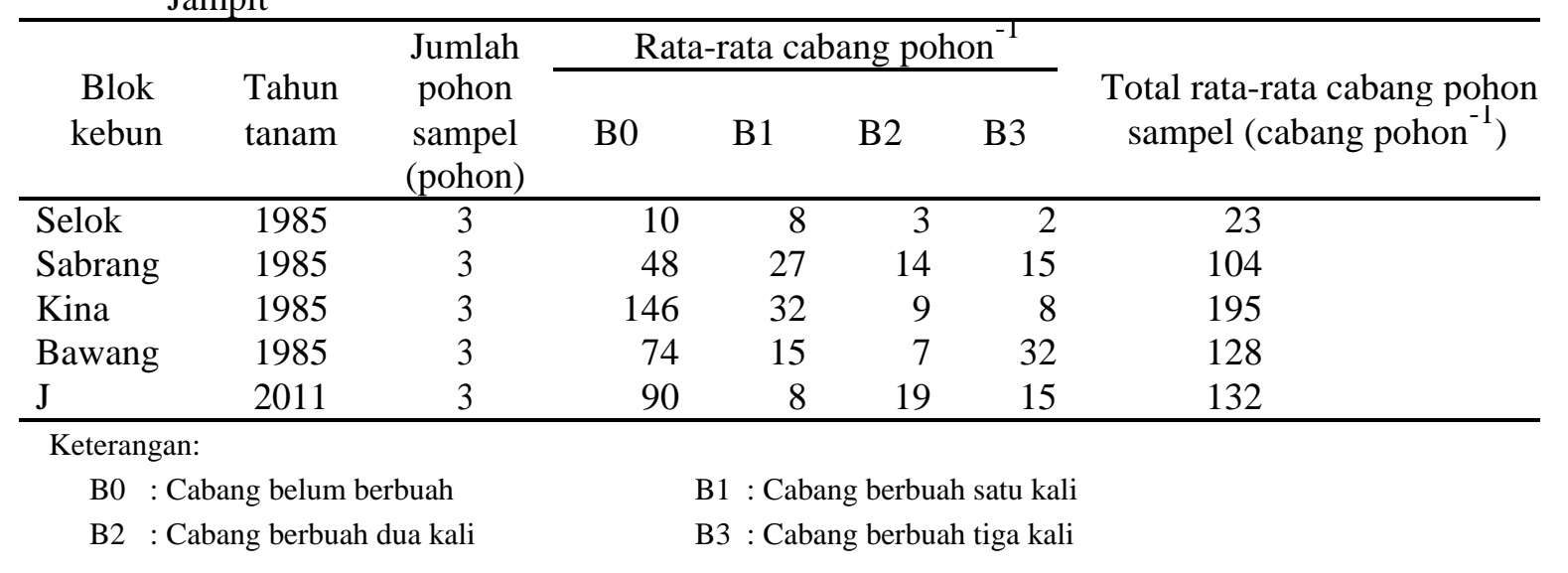


Tabel 2. Persentase jumlah cabang berdasarkan komposisi cabang dan hasil taksasi produksi tanaman kopi Arabika di Afdeling Kampung Baru Kebun Kalisat Jampit

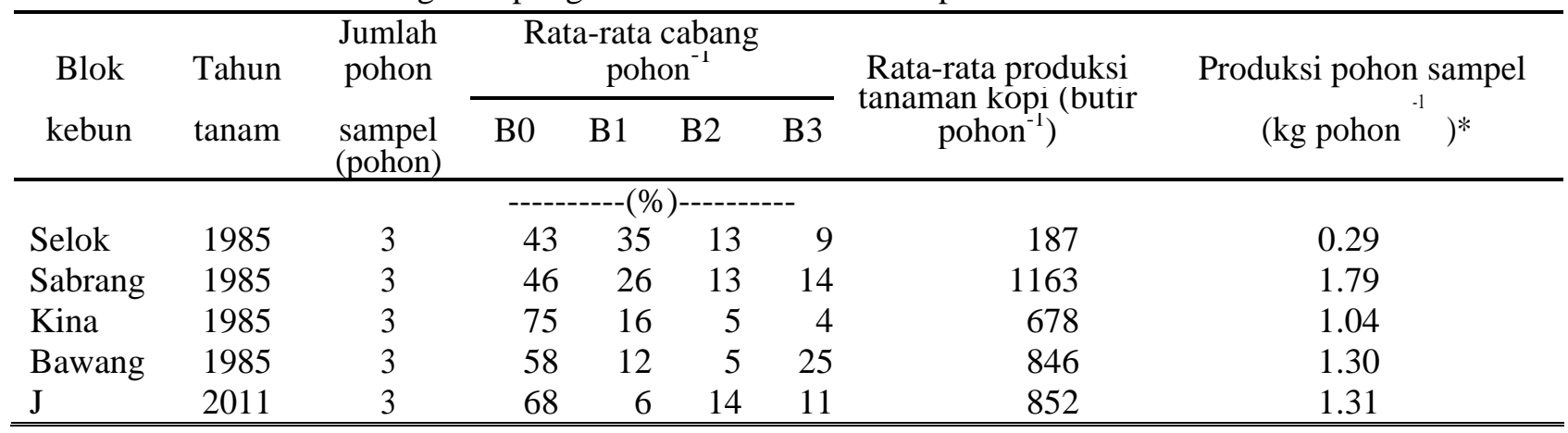

*Hasil diskusi dan wawancara dengan pihak kebun

\section{Cabang Produktif dan Cabang Tidak Produktif}

Pemangkasan produksi/pemeliharaan dilakukan pada TM. Wiwil halus dilakukan dengan memangkas cabang-cabang adventif seperti cabang kering, cabang sakit, cabang balik. Pemangkasan juga dilakukan agar unsur hara dapat bermanfaat untuk mendorong pembentukan cabang-cabang reproduksi baru. Pengamatan ratarata cabang produktif dan cabang tidak produktif disajikan dalam Tabel 3.

Berdasarkan hasil pengamatan pada Tabel 3 , rata-rata cabang yang produktif sebelum dan sesudah pemangkasan tidak jauh berbeda. Ratarata cabang produktif paling banyak terdapat pada Blok Kina (79.7 cabang pohon ${ }^{-1}$ ), sedangkan untuk Blok Selok merupakan yang paling sedikit (22.3 cabang pohon ${ }^{-1}$ ). Rata-rata cabang yang tidak produktif paling banyak adalah Blok $\mathbf{J}$ di mana terdapat banyak cabang yang kering. Berdasarkan Tabel 3, jumlah cabang tidak produktif sesudah pemangkasan lebih banyak disebabkan banyak cabang tidak produktif yang tertinggal pada saat pemangkasan dan tanaman terserang penyakit.

Secara keseluruhan berdasarkan hasil pengamatan, jumlah cabang yang produktif lebih banyak daripada cabang yang tidak produktif. Hal ini karena cabang-cabang yang tidak produktif telah dipangkas. Akan tetapi, dalam pelaksanaannya masih terdapat cabang tidak produktif yang terlewat dipangkas. Tanaman kopi akan menghasilkan cabang-cabang produktif baru apabila segera dilakukan pemangkasan.

\section{Tinggi Tanaman Setelah Pemangkasan}

Pemangkasan dilakukan agar tanaman tumbuh tidak terlalu tinggi sehingga mudah dalam pemeliharaan serta memudahkan karyawan dalam melakukan pemetikan buah kopi (Rahardjo, 2012). Tinggi tanaman kopi menghasilkan menurut standar yang ditetapkan oleh kebun yaitu tidak lebih dari $170 \mathrm{~cm}$. Pengamatan dilakukan dengan mengukur tinggi tanaman sebanyak dua kali yakni sebelum dan setelah pemangkasan serta mengukur jarak antar cabang primer. Pengukuran tinggi tanaman dilakukan menggunakan alat meteran dan diukur dari permukaan tanah hingga titik teratas tunas. Hasil pengamatan tinggi tanaman kopi disajikan pada Tabel 4.

Hasil pengamatan pada Tabel 4, menunjukkan bahwa rata-rata tinggi tanaman sampel sesuai dengan standar yaitu tidak lebih dari $170 \mathrm{~cm}$. Tanaman kopi pada Blok J memiliki ketinggian yang lebih besar dibandingkan dengan blok lainnya yaitu $154 \mathrm{~cm}$, sedangkan Blok Kina memiliki rata-rata tinggi tanaman kopi paling rendah $(123 \mathrm{~cm})$ diantara lima blok sampel. Tinggi tanaman kopi setelah pemangkasan lebih besar karena terdapat tunas baru yang tumbuh sehingga tinggi tanaman bertambah dari sebelum pemangkasan.

Selain tinggi tanaman, jarak antar cabang pada tanaman kopi juga di amati. Jarak antar cabang paling rapat terdapat pada Blok Sabrang. Hal ini karena cabang primer pada blok tersebut tumbuh lebih banyak, sehingga jarak antar cabang lebih rapat. Ruas batang pada tanaman kopi Arabika berkisar antara 2-9 cm (Ditjenbun, 2014). Perbedaan jarak antar cabang primer untuk masing-masing tanaman mungkin dikarenakan kondisi kesuburan tanaman yang berbeda dan cabang tanaman lebih sering dipelihara dengan baik.

\section{Pertumbuhan Tunas Setelah Pemangkasan}

Setelah dilakukan pemangkasan pada cabang-cabang yang tidak produktif seperti cabang kering dan cabang sakit, akan tumbuh tunas baru seperti tunas air dan cabang-cabang reproduksi. Pengamatan pertumbuhan tunas setelah pemangkasan disajikan dalam Tabel 5. 
Tabel 3. Rata-rata jumlah cabang-cabang produktif dan cabang-cabang tidak produktif tanaman kopi Arabika di Afdeling Kampung Baru Kebun Kalisat Jampit

\begin{tabular}{|c|c|c|c|c|c|c|}
\hline \multirow{2}{*}{$\begin{array}{l}\text { Blok } \\
\text { kebun }\end{array}$} & \multirow{2}{*}{$\begin{array}{l}\text { Tahun } \\
\text { tanam }\end{array}$} & \multirow{2}{*}{$\begin{array}{c}\text { Jumlah } \\
\text { pohon } \\
\text { sampel } \\
\text { (pohon) }\end{array}$} & \multicolumn{2}{|c|}{$\begin{array}{l}\text { Rata-rata cabang } \\
\text { produktif (cabang } \\
\left.\text { pohon }^{-1}\right)\end{array}$} & \multicolumn{2}{|c|}{$\begin{array}{c}\text { Rata-rata cabang tidak produktif (cabang } \\
\text { pohon }{ }^{-1} \text { ) }\end{array}$} \\
\hline & & & $\begin{array}{l}\text { Sebelum } \\
\text { pangkas }\end{array}$ & $\begin{array}{c}\text { Setelah } \\
\text { pangkas }\end{array}$ & $\begin{array}{c}\text { Sebelum } \\
\text { pangkas }\end{array}$ & $\begin{array}{c}\text { Setelah } \\
\text { Pangkas } \\
\end{array}$ \\
\hline Selok & 1985 & 3 & 12.7 & 22.3 & 6 & 6.3 \\
\hline Sabrang & 1985 & 3 & 56.7 & 45.3 & 2.3 & 9.7 \\
\hline Kina & 1985 & 3 & 49.3 & 79.7 & 16 & 6 \\
\hline Bawang & 1985 & 3 & 53.3 & 54.3 & 10 & 9 \\
\hline J & 2011 & 3 & 42.7 & 65.3 & 16.7 & 20.7 \\
\hline
\end{tabular}

Tabel 4. Rata-rata tinggi tanaman dan jarak antar cabang tanaman kopi Arabika di Afdeling Kampung Baru Kebun Kalisat Jampit

\begin{tabular}{|c|c|c|c|c|c|}
\hline \multirow{2}{*}{$\begin{array}{l}\text { Blok } \\
\text { kebun }\end{array}$} & \multirow{2}{*}{$\begin{array}{l}\text { Tahun } \\
\text { tanam }\end{array}$} & \multirow{2}{*}{$\begin{array}{l}\text { Jumlah } \\
\text { pohon } \\
\text { sampel } \\
\text { (pohon) }\end{array}$} & \multicolumn{2}{|c|}{$\begin{array}{l}\text { Rata-rata tinggi tanaman } \\
\qquad(\mathrm{cm})\end{array}$} & \multirow{2}{*}{$\begin{array}{l}\text { Rata-rata jarak antar } \\
\text { cabang di pohon sampe } \\
(\mathrm{cm})\end{array}$} \\
\hline & & & $\begin{array}{l}\text { Sebelum } \\
\text { pangkas }\end{array}$ & $\begin{array}{l}\text { Setelah } \\
\text { pangkas }\end{array}$ & \\
\hline Selok & 1985 & 3 & 144.7 & 152.7 & 7.4 \\
\hline Sabrang & 1985 & 3 & 141.3 & 143 & 4.9 \\
\hline Kina & 1985 & 3 & 118.7 & 123 & 8.7 \\
\hline Bawang & 1985 & 3 & 141 & 149 & 7.7 \\
\hline $\mathrm{J}$ & 2011 & 3 & 154 & 154 & 6.1 \\
\hline
\end{tabular}

Tabel 5. Jumlah tunas yang tumbuh setelah pemangkasan tanaman kopi Arabika di Afdeling Kampung Baru Kebun Kalisat Jampit

\begin{tabular}{lccc}
\hline \multicolumn{1}{c}{ Blok kebun } & Tahun tanam & $\begin{array}{c}\text { Jumlah pohon } \\
\text { sampel (pohon) }\end{array}$ & Tunas yang tumbuh (tunas) \\
\hline Selok & 1985 & 3 & 5.3 \\
Sabrang & 1985 & 3 & 5.7 \\
Kina & 1985 & 3 & 5.0 \\
Bawang & 1985 & 3 & 2.3 \\
J & 2011 & 3 & 6.7 \\
\hline
\end{tabular}

Berdasarkan Tabel 5, pertumbuhan tunas tidak terlalu mengalami perbedaan. Pertumbuhan tunas di Blok $\mathbf{J}$ paling tinggi dibandingkan blok lain yaitu sebesar 6.7 tunas, sedangkan Blok Bawang mengalami pertumbuhan tunas paling rendah. Pertumbuhan tunas baru setelah dilakukan pemangkasan mungkin saja dipengaruhi oleh faktor kesuburan serta keadaan iklim mikro kebun setempat. Pertumbuhan tunas baru akan mempengaruhi komposisi cabang pada tahun selanjutnya. Cabang-cabang yang dipangkas saat ini akan berpengaruh terhadap jumlah cabang serta produksi tahun yang akan datang.

\section{KESIMPULAN}

Kegiatan penelitian di Kebun Kalisat Jampit telah meningkatkan pengetahuan dan pengalaman, keterampilan kerja, kemampuan teknis, serta manajerial mengenai teknik budidaya tanaman kopi, khususnya pemangkasan. Kegiatan pemangkasan di Kebun Kalisat Jampit sebagian besar sudah baik (sesuai dengan standar kebun). Hal ini dapat dilihat dari tinggi tanaman yang ada di kebun tidak lebih dari $170 \mathrm{~cm}$, meskipun proporsi jumlah cabang B0, B1, B2 belum mencapai proporsi seimbang (masing-masing cabang $\pm 33 \%$ ) dan masih terdapat cabang-cabang kering serta tidak produktif disebabkan terlewat saat dipangkas. Pemangkasan yang dilakukan merupakan pemangkasan pemeliharaan yang terdiri atas wiwil kasar dan wiwil selektif. Cabang-cabang yang dipangkas saat ini akan berpengaruh terhadap jumlah cabang dan produksi tahun yang akan datang. 


\section{DAFTAR PUSTAKA}

Atrisiandy, K. 2015. Pemangkasan Kopi. Balai Pengkajian Teknologi Pertanian, Sumatera Utara, ID.

[BPS] Badan Pusat Statistik. 2018. Statistik Kopi Indonesia 2017. Badan Pusat Statistik, ID.

[Ditjenbun] Direktorat Jenderal Perkebunan. 2014. Pedoman Teknis Budidaya Kopi

Agriculture Practices/ GAP on Coffe). Direktorat Jenderal Perkebunan, Jakarta, ID.

[Ditjenbun] Direktorat Jenderal Perkebunan. 2015. Statistik Perkebunan Indonesia Komoditas

2014-2016. Direktorat Jenderal Perkebunan, Jakarta, ID.

Martini, E., Riyandoko, J. M. Roshetko. 2017. Pedoman Membangun Kebun Agroforestry Kopi.
Agroforestry Centre (ICRAF) Southeast Asia Regional Program, Bogor, ID.

Mulyono, Hairunnas, Kaslil. 2016. Akibat pola pemangkasan terhadap kualitas dan rendemen kopi Arabika (Coffea arabica L.). J. Ilmiah Res. Sains. 2(3):53-68.

Panggabean, E. 2011. Buku Pintar Kopi. AgroMedia Pustaka, Jakarta, ID.

Rahardjo, P. 2012. KopiangandlBaikB (iGiobdya dan Pengolahan Kopi Arabika dan Kopi Robusta. Penebar Swadaya, Jakarta, ID.

Rahardjo, P. 2017. Berkebun Kopi. Penebar Swadaya, Jakarta, ID.

Subandi, M. 2011. Buklidaiya Tanaman Perkebunan. Gunung Djati Press, Bandung, ID.

Sudarko. 2012. Tingkat kemampuan anggota kelompok tani dalam penerapan inovasi teknologi kopi rakyat. JSEP. 6(1)H5orld usahatani 